\title{
ANALISIS PENGAKUAN PENDAPATAN TIKET ANGKUTAN KOTA PADANG (STUDI KASUS UPT TRANS PADANG)
}

\author{
FITRI YULIANIS, PUGUH SETIAWAN, JEKRI SALMA NISRA \\ fitriyulianis@umsb.ac.id \\ Universitas Muhammadiyah Sumatera Barat
}

\begin{abstract}
Abstrak: Penelitian ini bertujuan dari untuk menganalisis pengakuan pendapatan dari penjualan tiket Trans Padang tahun 2018.

Hasil Penelitian ini menunjukkan bahwa Pendapatan yang diperoleh oleh Trans Padang adalah pendapatan yang berasal dari penjualan tiket angkutan bus yang terdiri dari dua macam tiket yaitu TAT dan tiket elektronik. Hasil analisis pendapatan penjualan tiket pada Trans Padang ini mengunakan metode basis kas yaitu pendapatan diakui pada saat penjualan terealisasi. Pendapatan dari penjuaan tiket merupakan usur paling utama kegiatan Trans Padang ini.

Dalam pencatatan laporan keuangan masih menggunakan metode manual sehingga banyak terjadi kesalahan-kesalahan yang signifikan diantaranya terdapatnya kesalahan pencatatan dari jumlah penjualan tiket pada tabel-tabel laporan pendapatan, terdapatnya kecurangan dari penjualan tiket sehingga sangat perpengaruh terhadap pendapatan Trans Padang dalam mencapai target yang telah ditetapkan, contohnya tidak diberikannya tiket kepada penumpang, tiket dibayar dibawah harga tiket tetapi tanpa memberikan tiket pada penumpang, dan terjadinya pembayaran dobel oleh penumpang yang mengira tiketnya belum dibayarkan temanya sehingga dibayar lagi oleh penumpang yang sama.
\end{abstract}

Kata Kunci : Pendapatan, Cash Basis

\section{A. Pendahuluan}

Fadhilo (2017) berpendapat bahwa transportasi merupakan sarana yang sangat penting dan dominan dalam mempermudah dan memperlancar roda perekonomian. Transportasi berperan penting sebagai penunjang, pendorong, penggerak bagi pertumbuhan suatu daerah, baik daerah perkotaan maupun daerah pedesaan. Salah satu sarana penting dari subsektor angkutan darat yang ada di Indonesia adalah kendaraan bermotor. Menurut Badan Pusat Statistik (2018), kendaraan bermotor bagian darat dapat dibedakan menjadi empat jenis yaitu mobil penumpang, bis, mobil barang dan sepeda motor.

Bus kota yang merupakan salah satu transportasi yang dipilih oleh masyarakat sebagai kendaraan umum dari masa lalu hingga masa kini. Pengoperasian bus ini memiliki beberapa aspek yakni dari aspek lingkungan, sosial dan ekonomi (Fadhilo, 2017). Pendapatan perusahaan auto bus didapatkan dari tarif yang harus dibayar oleh pemakai jasa transportasi, hingga perhitungan harga pokok tiket sebagai salah satu dasar didalam penentuan tarif atau harga jual yang merupakan faktor penting karena dapat mempengaruhi profitabilitas suatu perusahaan auto bus (Gayatri, 2014).

Pendapatan adalah jumlah uang yang diterima oleh perusahaan dari aktivitasnya, kebanyakan dari penjualan jasa kepada pelanggan. Bagi investor pendapatan kurang penting dibandingkan keuntungan, yang merupakan jumlah uang yang diterima setelah dikurangi pengeluaran. Pertumbuhan pendapatan merupakan 
indikator penting penerimaan pasar dari produk jasa perusahaan tersebut. Pertumbuhan pendapatan yang konsisten dan juga pertumbuhan keuntungan, dianggap penting bagi perusahaan yang dijual ke publik melalui saham untuk menarik investor (Wulandari, 2013). Pengkuan perlu dilakukan pada saat yang tepat atas suatu kejadian ekonomi yang menghasilkan pendapatan, begitu juga jumlah yang diakui secara tempat agar tidak mengakibatkan kesalahan informasi yang disajikan dalam laporan laba rugi dan juga dalam pengambilan keputusan (Apsa, 2014).

Salah satu yang meningkatkan profitabilitas dari perusahaan dibidang jasa transportasi adalah pendapatan dari penjualan tiket. Rahmat dan Oktaviano (2016), mengemukakan bahwa tiket merupakan salah satu dokumen perjalanan yang dikeluarkan oleh perusahaan untuk menerapkan suatu kontrak tertulis dari satu pihak yang berisikan ketentuan yang harus dipenuhi penumpang selama memakai jasa tiket serta data penumpang yang mempunyai masa periode waktu tertentu. Pentingnya tiket untuk pelangan sebagai alat bukti pembayaran yang menyatakan adanya perjanjian antara penyedia dan pengguna jasa didalam pengangkutan ke berbagai tujuan yang telah disepakati kedua belah pihak antara penyedia dan pengguna tiket (Rahmat dan Oktaviano, 2016).

Trans Padang merupakan layanan angkutan masal Bus Rapid Transit (BRT) di Kota Padang yang mulai beroperasi pada Januari 2014. Koridor yang telah beroperasi adalah pada rute Lubuk Buaya-Pasar Raya. Bus Trans Padang memiliki kapasitas penumpang sebanyak 40 orang, yang terdiri dari 20 orang penumpang dengan fasilitas tempat duduk, dan 20 orang penumpang berdiri dengan fasilitas pegangan tangan. Bus Trans Padang dilengkapi fasilitas tempat duduk prioritas untuk para penumpang lanjut usia, ibu hamil, penumpang dengan membawa anak serta penumpang dengan kebutuhan khusus. Bus ini beroperasi setiap hari, mulai dari pukul 06.00 WIB hingga 20.00 WIB. Tiket penumpang dapat dibeli dalam bus dengan tarif sebesar Rp. 1.500,untuk pelajar dan Rp. 3.500,- untuk umum per satu kali perjalanan (flat) jauh atau dekat.

Dalam Trans Padang ini sesuai dengan peraturan Wali Kota Padang yang tertera pada nomor 28 tahun 2013 pasal 8 yang menjelaskan unit pelaksanaan Trans Padang, yaitu tentang pelaksanaan urusan pendapatan. Pelaksanaan urusan pendapatan mempunyai tugas pokok membantu kepala sub bagian tata usaha dalam menyelenggarakan penatausahaan terhadap seluruh penerima dan penyetoran atas penerimaan yang menjadi tanggung jawabnya.

Di Trans padang, perhitungan pendapatan dilakukan dari penjualan tiket. Pengakuan pendapatan dalam periode tertentu sangatlah penting selama pelaksanaan yang berhubungan dengan usaha. Dalam pengakuan pendapatan terdapat metode pengakuan dari penjualan tiket angkutan yang menjadi acuan dalam pengakuannya. Menurut Nurianti (2013) tujuan pengakuan pendapatan adalah untuk menentukan kapan suatu penghasilan diakui sebagai pendapatan dan biaya diakui sebagai beban. Adapun metode yang digunakan yaitu cass basic dan acrual basic. Apabila cash basic yang digunakan maka pendapatan diakui pada saat kas diterima dan apabila acrual basic yang digunakan maka pendapatan diakui pada saat pendapatan itu dihasilkan walaupun secara fisik kas belum diterima.

Penelitian terdahulu yang menjadi referensi dan informasi tambahan dalam penelitian ini dapat dilihat pada Tabel 
Tabel

Penelitian Terdahulu

\begin{tabular}{|c|c|c|c|}
\hline NO & Nama Peneliti & Tahun & Hasil \\
\hline 1 & $\begin{array}{l}\text { Septiono dkk } \\
\text { Metode Pengakuan } \\
\text { Pendapatan dan Beban } \\
\text { Terhadap Kewajiban } \\
\text { Laporan Keuangan (Studi } \\
\text { Kasus Pada PT Petrosida } \\
\text { Gresik). }\end{array}$ & 2015 & $\begin{array}{l}\text { 1. Penerapan metode pengakuan pendapatan pada PT. } \\
\text { Petrosida Gresik menggunakan metode pengakuan } \\
\text { pendapatan pada saat penjualan maka penerapannya } \\
\text { tersebut sesuai Pernyataan Standar Akuntansi Keuangan } \\
\text { (PSAK) No. } 23 \text { tentang pendapatan. } \\
\text { 2. Terdapat kesalahan dalam mengakui pendapatan melalui } \\
\text { agen tidak memisahkan fee penjualan kepada agen pada } \\
\text { penjualan yang mana pada Standar Akuntansi Keuangan } \\
\text { (SAK)telah dijelaskan fee penjualan agen terhadap } \\
\text { penjualan. }\end{array}$ \\
\hline 2 & $\begin{array}{l}\text { Sa'diyah dan Sutarti } \\
\text { Analisis Pengakuan dan } \\
\text { Beban Serta Pengaruhnya } \\
\text { Terhadap Laporan Rugi } \\
\text { Laba (Studi Kasus Pada } \\
\text { PD Jasa Transportasi). }\end{array}$ & 2014 & $\begin{array}{l}\text { Pada perusahaan daerah jasa transportasi mengakui } \\
\text { pendapatan dengan mengunakan metode akrual basic, dimana } \\
\text { pendapatan diakui pada saat penjualan terealisasi. }\end{array}$ \\
\hline 3 & $\begin{array}{l}\text { Apsa } \\
\text { Evaluasi Pengakuam, } \\
\text { Pengukuran dan } \\
\text { Pelaporan Pendapatan } \\
\text { Berdasarkan PSAK No } \\
23 \text { Pada PT. Pelayanan } \\
\text { Liba Marindo } \\
\text { Tanjungpinang Periode } \\
\text { 2013. }\end{array}$ & 2014 & $\begin{array}{l}\text { Pengakuan pendapatan pada PT. Liba Marindo dilakukan } \\
\text { dengan mengungkapkan dua cara, yaitu dengan mengakui } \\
\text { pendapatan pada saat kas diterima (tunai) dan pada saat } \\
\text { transaksi telah dilakukan meskipun pembayaran belum } \\
\text { sepenuhnya terbayarkan.Namun perusahaan dalam } \\
\text { prakteknya diakhir tahun pada laporan keuangannya tidak } \\
\text { mencatat pendapatan non tunai yang sesungguhnya. Hal ini } \\
\text { dikarenakan pendapatan yang diterima dari pelangan dibulan } \\
\text { Desember baru akan diakui perusahaan dibulan Januari. } \\
\text { Sehingga laporan keuangannya tidak menunjukkan hasil yang } \\
\text { sebenarnya dan menyimpang pada ketentuan PSAK No.23. }\end{array}$ \\
\hline 4 & $\begin{array}{l}\text { Wulandari } \\
\text { Pengaruh Perubahan } \\
\text { Pendapatan Penjualan } \\
\text { Tiket Pesawat dan Kapal } \\
\text { Pelni Terhadap } \\
\text { Perubahan Laba } \\
\text { Perusahaan Pada PT. } \\
\text { Pesona Bintang Tours } \\
\text { dan Travel }\end{array}$ & 2013 & $\begin{array}{l}\text { Pendapatan penjualan tiket pesawat berpengaruh signifikan } \\
\text { terhadap perubahan labadan pendapatan penjualan tiket kapal } \\
\text { Pelni tidak terdapat pengaruh yang signifikat terhadap } \\
\text { perubahan laba. }\end{array}$ \\
\hline
\end{tabular}

Berdasarkan uraian latar belakang masalah pada penelitian di atas maka tujuan dari penelitian ini adalah untuk Menganalisis Pengakuan Pendapatan dari penjualan tiket Trans Padang. 
Kerangka Pemikiran dari Penelitian ini

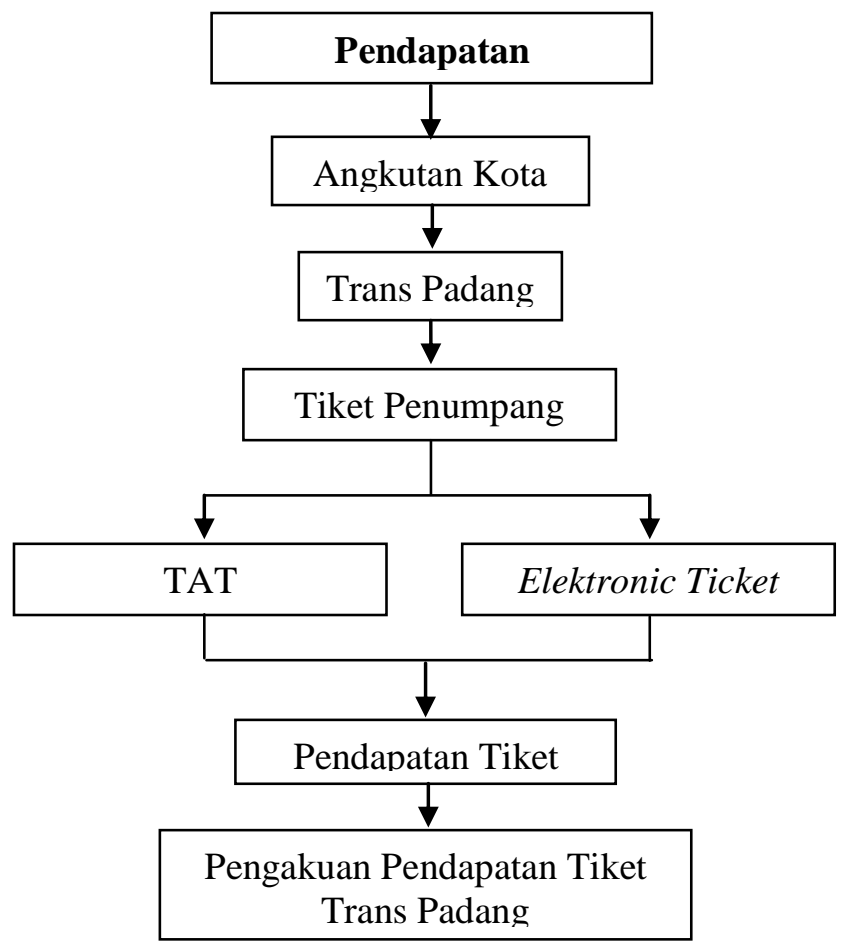

\section{B. Metode Penelitian}

Penelitian ini adalah penelitian kualitatif yang berlandaskan pada filsafat positivisme, digunakan untuk meneliti pada kondisi obyek yang alamiah sebagai lawannya adalah eksperimen (Sugiyono, 2011).

Penelitian ini dilakukan di UPT Trans Padang, Kota Padang, Sumatera Barat pada bulan Januari 2019 dimana teknik pengumpulan data yang digunakan dalam penelitian ini adalah: Wawancara

Wawancara adalah proses tanya jawab lisan dimana dua orang atau lebih bertatap muka secara fisik untuk mengetahui tanggapan, pendapatan dan motivasi seseorang terhadap suatu obyek (Soegijono, 1993). Teknik wawancara yang dilakukan dalam pengumpulan data penelitian ini berupa wawancara langsung dengan manajemen perusahaan, kepala bagian serta dua orang karyawan yang terkait dengan penjualan tiket dan laporan pendapatan perusahaan.

Sumber data

Sumber data dalam penelitian ini dibedakan menjadi dua yaitu:

a. Data primer

Menurut Widhjono (2007), data primer adalah bukti penulisan yang diperoleh di lapangan yang dilakukan secara langsung oleh penulisnya. Untuk pembuktian suatu kasus penulisan ilmiah (laporan), penulis mengumpulkan data atau informasi secara cermat dan tuntas. Data primer yang dikumpulkan di lapangan berupa alur penjualan tiket di bus Trans Padang.

b. Data sekunder

Menurut Widhjono (2007), data sekunder adalah bukti teoritik yang diperoleh melalui studi pustaka. Data ini mendasari kajian teoritik yang digunakan sebagai landasan kerangka berfikir. Berdasarkan kajian teoritik ini dapat disusun hipotesis (kerangka konsep) yang mendasari keseluruhan karangan. 
Data sekunder dalam penelitian ini berupa bahan-bahan reverensi tentang pengakuan pendapatan, dokumen-dokumen perusahaan tentang profil perusahaan, laporan pendapatan dan stuktur organisasi UPT Trans padang.

Teknik Observasi

Menurut Young dalam Indrawati dkk (2007), observasi adalah suatu studi yang dilakukan dengan sengaja/terencana dan sistematis melalui penglihatan/pengamatan terhadap gejala-gejala spontan yang terjadi saat ini. Teknik pengumpulan data berupa observasi dilakukan dengan melakukan pengamatan secara langsung pada kegiatan wawancara dan proses transaksi penjualan tiket di UPT Trans Padang.

\section{Teknik Analisis Data}

Data yang telah dikumpulkan akan dianalisis dengan mengunakan teknik analisis deskriptif kualitatif. Menurut Prabowo dan Heriyanto (2013), teknik deskriptif kualitatif adalah metode pengolahan data dengan cara menganalisis faktor-faktor yang berkaitan dengan objek penelitian dengan penyajian data secara lebih mendalam terhadap objek penelitian. Teknik analisis data deskriptif kualitatif dalam penelitian ini berupa pendeskripsian, penjabaran, penyajian dan penganalisaan tentang pendapatan tiket angkutan Trans Padang di UPT Trans Padang.

\section{Pembahasan}

Tahun 2018 ini realisasi penumpang bus Trans Padang yang terlayani adalah sebanyak 2.619.075 karcis. Yang terdiri dari 616.285 karcis, dari penjualan tiket pada penumpang yang berprofesi sebagai pelajar, penjualan tiket kepada pelajar mayoritas terjadi pada saat pelajar berangkat kesekolah dan pulang dari sekolah. Sedangkan 1.962.790 karcis didapatkan dari penjualan kepada masyarakat umum. Rata-rata karcis yang didapatkan perhari selama 2018 adalah 7.175 karcis. Sedangkan penumpang yang menggunakan kartu Brizzi selama tahun 2018 adalah sebanyak 97.515.529 karcis/struk umum maupun pelajar, realisasi penjualan mengunakan karcis dan Brizzi dapat di lihat pada tabel pendapatan dari penjualan tiket pada tabel dibawah.

\section{Tabel}

\section{Pendapatan penjualan tiket}

\begin{tabular}{|c|c|c|c|c|c|c|c|c|c|}
\hline \multirow{3}{*}{ NO } & \multirow{3}{*}{ Bulan } & \multirow{2}{*}{\multicolumn{3}{|c|}{$\begin{array}{c}\text { Jenis Tiket (Lembar } \\
\text { Pelajar }\end{array}$}} & \multirow{2}{*}{\multicolumn{3}{|c|}{ Jumlah Penjualan Tiket (Rp) }} & \multirow{3}{*}{$\begin{array}{c}\text { Jumlah } \\
\text { Brizzi/Bulan }\end{array}$} & \multirow{3}{*}{ Jumlah Total } \\
\hline & & & & & & & & & \\
\hline & & Pelajar & Umum & $\mathrm{Jml}$ & Pelajar & Umum & $\mathrm{Jml}$ & & \\
\hline 1 & Januari & 59,567 & 196,385 & 255,952 & $89,350,500$ & $687,347,500$ & $776,698,000$ & $7,185,000$ & $783,883,000$ \\
\hline 2 & Februari & 54,772 & 162,612 & 217,384 & $82,158,000$ & $569,142,000$ & $651,300,000$ & $5,979,500$ & $657,279,500$ \\
\hline 3 & Maret & 55,595 & 154,842 & 210,437 & $83,392,500$ & $541,947,000$ & $625,339,500$ & $6,700,000$ & $632,039,500$ \\
\hline 4 & April & 38,391 & 171,702 & 210,093 & $57,586,500$ & $600,957,000$ & $658,543,500$ & $7,197,500$ & $665,741,000$ \\
\hline 5 & Mai & 30,674 & 143,136 & 173,810 & $46,011,000$ & $500,976,000$ & $546,987,000$ & $5,698,500$ & $552,685,500$ \\
\hline 6 & Juni & 13,225 & 108,261 & 121,486 & $19,837,500$ & $378,913,500$ & $398,751,000$ & $4,905,000$ & $403,656,000$ \\
\hline 7 & Juli & 63,056 & 215,517 & 278,573 & $94,584,000$ & $754,309,500$ & $848,893,500$ & $8,696,000$ & $857,589,500$ \\
\hline 8 & Agustus & 70,942 & 174,975 & 245,917 & $106,413,000$ & $612,412,500$ & $718,825,500$ & $11,774,500$ & $730,600,000$ \\
\hline
\end{tabular}

184 Lembaga Penelitian dan Penerbitan Hasil Penelitian Ensiklopedia $\quad$ E-ISSN: 2657-0300

P-ISSN: 2657-0319 


\begin{tabular}{|c|c|c|c|c|c|c|c|c|c|}
\hline 9 & September & 63,773 & 164,987 & 228,760 & $95,659,500$ & $577,454,500$ & $673,114,000$ & $11,479,500$ & $684,593,500$ \\
\hline 10 & Oktober & 70,047 & 192,153 & 262,200 & $105,070,500$ & $672,535,500$ & $777,606,000$ & $8,774,855$ & $786,380,855$ \\
\hline 11 & November & 61,374 & 163,084 & 224,458 & $92,061,000$ & $570,794,000$ & $662,855,000$ & $7,713,059$ & $670,568,059$ \\
\hline 12 & Desember & 34,867 & 115,136 & 150,003 & $52,300,500$ & $402,976,000$ & $455,276,500$ & $11,412,115$ & $466,688,615$ \\
\hline \multicolumn{2}{|r|}{ Jumlah } & 616,283 & $1,962,790$ & $2,579,073$ & $924,424,500$ & $6,869,765,000$ & $7,794,189,500$ & $97,515,529$ & $7,891,705,029$ \\
\hline \multicolumn{2}{|c|}{ Persentase } & & & & & & & & $75.50 \%$ \\
\hline
\end{tabular}

Sumber:Data di Olah Kembali

Terdapat penurunan penumpang baik yang menggunakan kartu Brizzi maupun yang membayar tunai pada bulan Juni dimungkinkan karenakan pada saat itu merupakan libur kuliah dan bulan puasa, dimana para pelajar sebagian besar tidak melakukan perjalanan kesekolah dikarenakan adanya pesantren ramadhan. Serta terjadi kenaikan pada bulan juli dikarenakan tahun ajaran baru dan mahasiswa baru banyak berdatangan dari daerah-daerah.

Tahun anggaran 2018 ini, target UPT Trans Padang yang ditetapkan adalah senilai Rp.10.452.778.000.,-. Realisasi pendapatan selama tahun 2018 senilai Rp. 7,891,975,029,-. atau realisasi pendapatan mencapai 76,84\%. Tabel (4.5) di bawah ini menjelaskan rincian pendapatan bulanan Trans Padang:

\section{Tabel}

\section{Realisasi Penjualan Tiket}

\begin{tabular}{|r|c|c|c|c|c|c|c|c|}
\hline \multirow{2}{*}{ no } & \multirow{2}{*}{ Bulan } & Target & \multicolumn{2}{|c|}{ Jumlah Penjualan Tiket (RP) } & $\begin{array}{c}\text { Penjualan } \\
\text { Brizzi }\end{array}$ & $\begin{array}{c}\text { Jumlah Total } \\
\text { Pendapatan }\end{array}$ & $\begin{array}{c}\text { Akumulasi } \\
\text { Penerimaan }\end{array}$ & Realisasi \\
\cline { 5 - 10 } & & Unum & Pelajar & & & & \\
\hline 1 & Januari & $871,064,833$ & $687,347,500$ & $89,350,500$ & $7,185,000$ & $783,883,000$ & $783,883,000$ & $7.50 \%$ \\
\hline 2 & Februari & $1,742,129,667$ & $569,142,000$ & $82,158,000$ & $5,979,500$ & $657,279,500$ & $1,441,162,500$ & $13.79 \%$ \\
\hline 3 & Maret & $2,613,194,500$ & $541,947,000$ & $83,392,500$ & $6,700,000$ & $632,039,500$ & $2,073,202,000$ & $19.83 \%$ \\
\hline 4 & April & $3,484,295,333$ & $600,957,000$ & $57,586,500$ & $7,197,500$ & $665,741,000$ & $2,738,943,000$ & $26.20 \%$ \\
\hline 5 & Mai & $4,355,324,167$ & $500,976,000$ & $46,011,000$ & $5,698,500$ & $552,685,500$ & $3,291,628,500$ & $31.49 \%$ \\
\hline 6 & Juni & $5,226,389,000$ & $378,913,500$ & $19,837,500$ & $4,905,000$ & $403,656,000$ & $3,695,284,500$ & $35.35 \%$ \\
\hline 7 & Juli & $6,097,453,833$ & $754,309,500$ & $94,854,000$ & $8,696,000$ & $857,859,500$ & $4,553,144,000$ & $43.56 \%$ \\
\hline 8 & Agustus & $6,967,518,667$ & $612,412,500$ & $106,413,000$ & $11,774,500$ & $730,600,000$ & $5,283,744,000$ & $50.55 \%$ \\
\hline 9 & September & $7,839,583,500$ & $577,454,500$ & $95,659,500$ & $11,479,500$ & $684,593,500$ & $5,968,337,500$ & $57.10 \%$ \\
\hline 10 & Oktober & $8,710,648,333$ & $672,535,500$ & $105,070,500$ & $8,774,855$ & $786,380,855$ & $6,754,718,355$ & $64.62 \%$ \\
\hline 11 & November & $9,581,713,167$ & $570,794,000$ & $92,061,000$ & $7,713,059$ & $670,568,059$ & $7,425,286,414$ & $71.04 \%$ \\
\hline 12 & Desember & $10,452,778,000$ & $402,976,000$ & $52,300,500$ & $11,412,115$ & $466,688,615$ & $7,891,975,029$ & $75.50 \%$ \\
\hline & & $6,869,765,000$ & $924,694,500$ & $97,515,529$ & $7,891,975,029$ & & \\
\hline
\end{tabular}

Sumber:UPT Trans Padang Data di Olah Kembali

Dalam penelitian ini peneliti sebagai salah satu penguna angkutan ini sering melihat kejadian pada saat pramugara melakukan penjulan tiket yang kerap kali tidak 
memberikan tiket kepada penumpang, dan dari hasil wawancara dengan beberapa orang seperti 1.) Ibuk anis salah satu pegawai swasta di Kota Padang yang sering menaiki bus Trans Padang mengakui bahwa ia pernah tidak diberikan tiket penumpang, 2.) peneliti melakukan wawancara dengan salah satu mahasiswa di kota padang dia mengatakan pernah membayar dengan harga yang lebih murah dari harga tiket, tanpa diberikan tiket, dan 3.) Penumpang beserta temannya saat berdesakdesakan mengaku pernah membayar dobel atau penumpang telah dibayarkan oleh temannya sedangkan penumpang membayarkan pula temannya tetapi pramugara dari bus tidak memberitahu, karena kurangnya kejujuran dari pramugara. Menurut pendapat mereka tentu itu merugikan bagi negara karena uang dari penjualan tiket masuk kedalam saku-saku orang yang tidak bertanggung jawab. Dari 10 orang yang saya wawancarai berpendapat hampir sama.

Kecurangan-kecurangan yang terjadi disebabkan kurangnya pengawasan dan peralatan canggih yang di gunakan dia bus Trans Padang agar mengurangi kecurangan sehingga tidak terjadi lagi. Kecurangan biasanya terjadi Pada jam- jam sibuk, biasanya banyak terjadi penumpukan atau kapasitas melebihi ketetapan, hal ini menjadi salah satu kecurangan dari petugas angkutan umum yang berdampak buruk terhadap pendapatanya.

Dari hasil wawancara dan juga pengamatan peneliti di UPT Trans Padang alur SOP pendistribusian tiket adalah sebagai berikut.

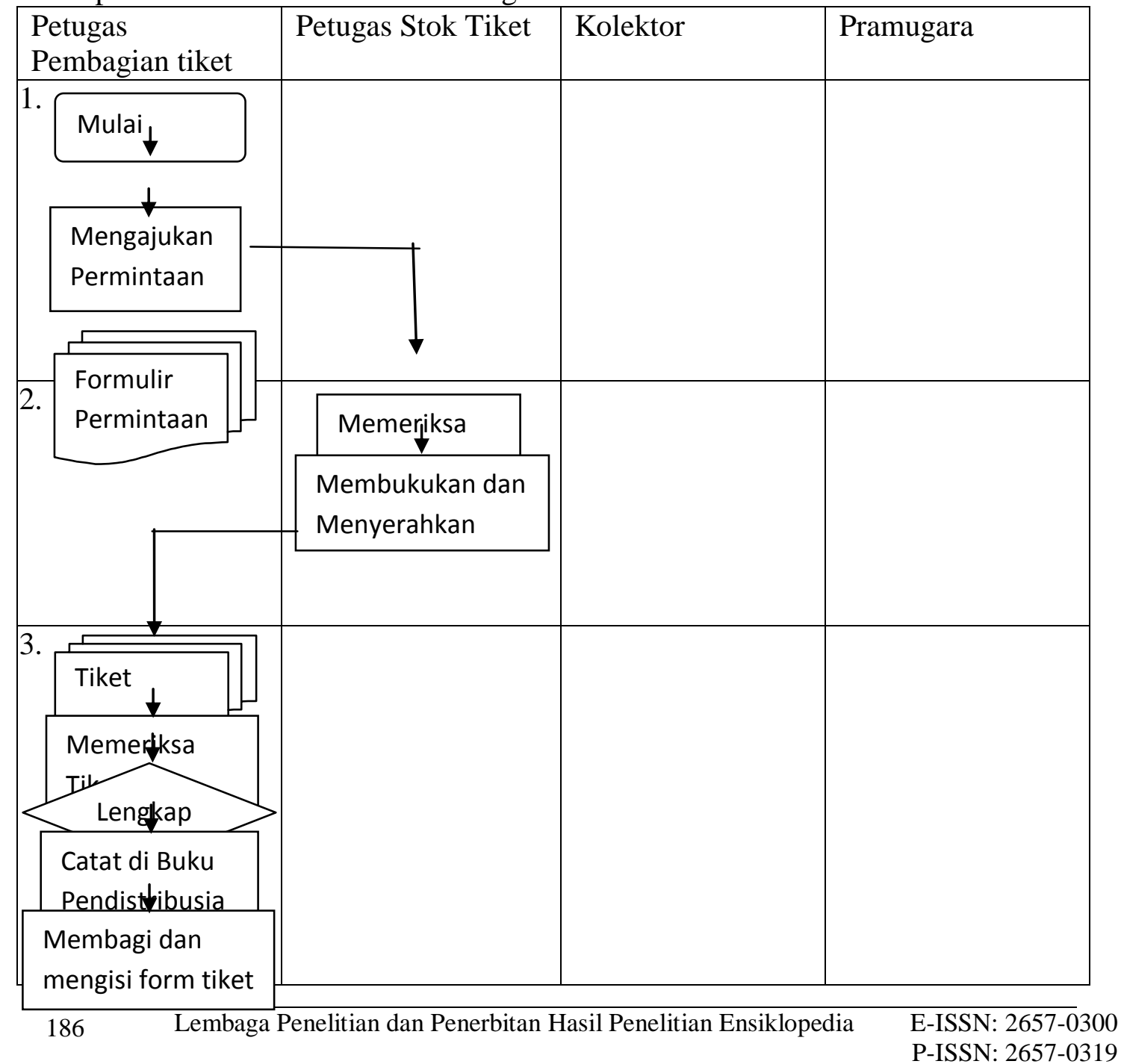




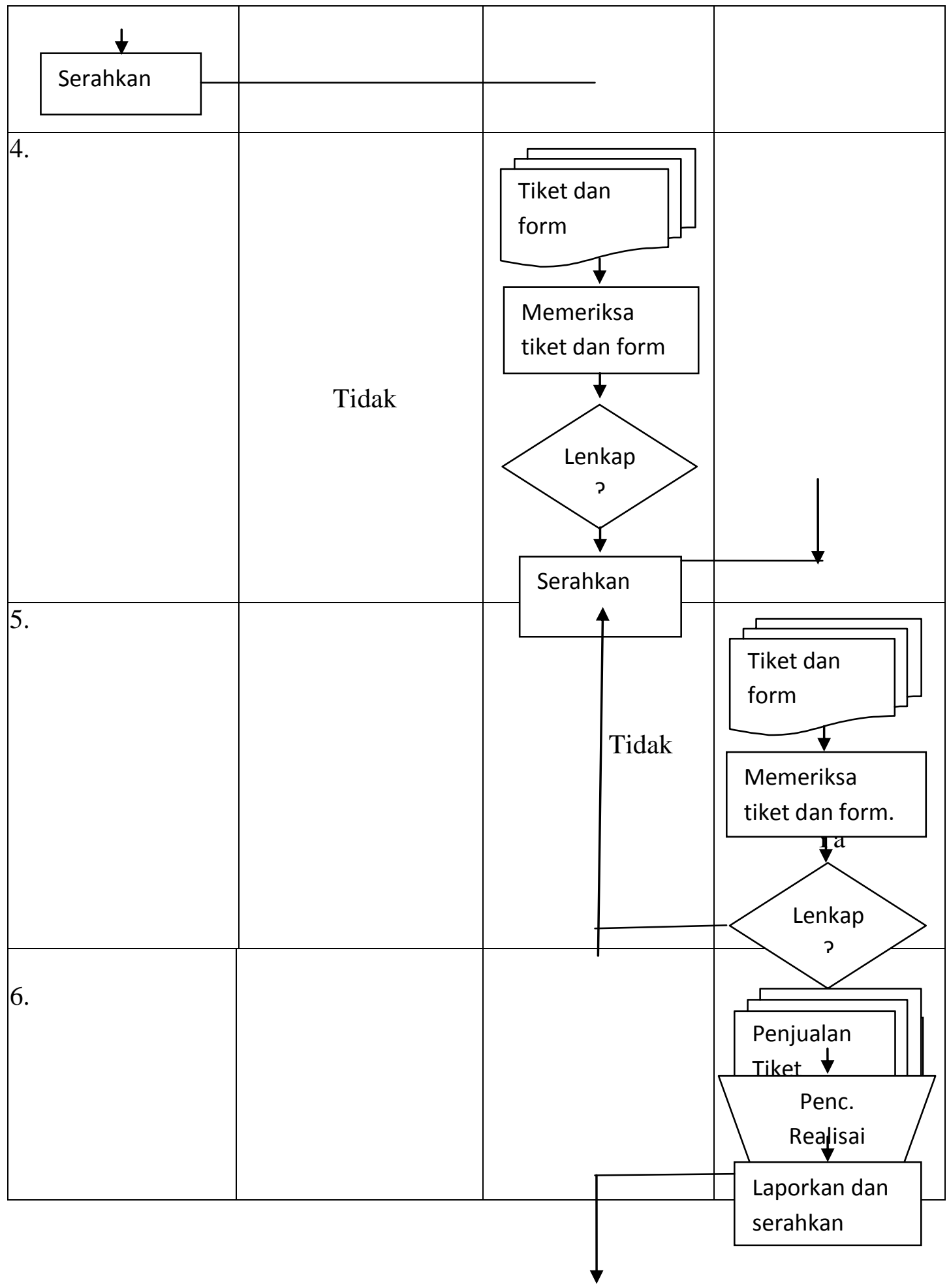




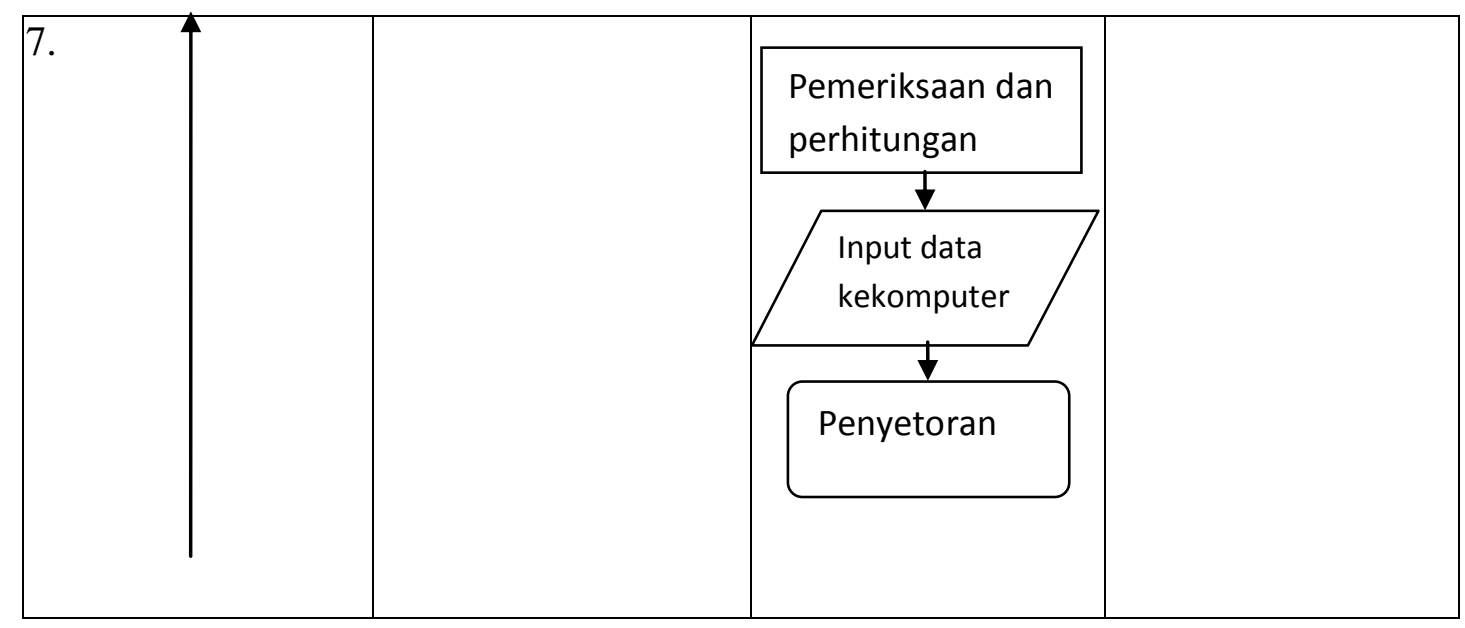

\section{Sumber: Diolah Sendiri}

1. Petugas pembagian tiket mengajukan permintaan tiket sesuai kebutuhan kepada petugas stok tiket dengan cara memberikan formulir permintaan tiket.

2. Petugas stok tiket memeriksa Formulir permintaan, menyiapkan tiket dan membukukan nomor tiket lalu menyerahkan tiket kepada petugas pembagian tiket.

3. Petugas pembagian tiket menerima tiket lalu memeriksa kesesuaian tiket dengan permintaan. Apabila tiket tidak sesuai akan dilaporkan kembali kepada petugas stok tiket dan apabila sesuai petugas pembagian akan mencatat di buku pendistribusian tiket.

Petugas pembagian tiket menyerahkan tiket kepada petugas kolektor dan mengisi formulir tiket sebagai bukti penyerahan.

Setelah menerima tiket dan formulir kolektor memeriksa tiket dan formulir apakah sesuai atau tidak. Setelah memeriksa, kolektor akan membagikan kepada petugas penjualan atau pramugara.

kolektor melakukan pengisian formulir pendistribusian tiket/karcis Trans Padang. Pencatatan rincian tiket per bus ditulis tangan/manual ke dalam formulir pendistribusian tiket contohnya petugas mengisikan Shift, hari tanggal, nomor dinding Bus, Nama pramugara, serta jumlah tiket yang diterima termasuk juga pencatatan nomor seri awal dan nomor seri akhir dari tiket, seperti gambar 4.3 dibawah.

Setiap harinya masing-masing petugas akan diberikan tiket sebanyak 300 lembar untuk umum dengan tiket bewarna pink dan 200 lembar untuk pelajar dengan tiket bewarna kuning.

4. Pramugara menerima tiket lalu memeriksa apakah tiket sesuai atau tidaknya jika tidak sesuai akan dilaporkan kembali kepada kolektor dan jika sesuai tiket akan di simpan pramugara.

5. Setelah jam pengoperasian bus pramugara akan menjual langsung tiket kepada penumpang bus yang mengunakan jasa angkutan Trans Padang ini, ada 2 jenis penjualan tiket yaitu penjualan secara TAT (Traditional Automated Ticket) dan tiket elektronik yaitu mengunakan kartu Brizi. Tiket di pasarkan dengan harga Rp 3.500 untuk umum, Rp 1.500 untuk pelajar.

Tiket TAT dapat dibeli setelah menaiki bus Trans Padang, sedangkan untuk mendpatkan kartu brizzi cukuplah gampang yaitu dengan cara 
mendaftarkan ke kantor-kantor cabang BRI, sales representatif Brizzi. Cara pengunaan kartu ini cukup mudah hanya dengan menempelkan kartu ke mesin pembaca maka transaksi akan segera diproses. Untuk melakukan pembayaran dari kartu brizzi ini tentunya kartu harus memiliki saldo, saldo dapat di isi dengan berbagai cara yaitu lansung membeli di kantor-kantor BRI terdekat, agen BRI Ling, Transfer dari atm BRI maupun bang lainnya.

Pada tiket TAT terdapat seri yang dengan kata-kata yang berbeda sebagai contoh seri: A, seri: C, D serta yang lainnya seri ini hanya sebagai simbol untuk mempermudah dalam pencatatan administrasi masing-masing terdiri dari nomor tiket 00.001 sampai 100.000 tiket.

6. Pencatatan realisasi penjualan oleh pramugara dan pengembalian sisa tiket pada kolektor. Kolektor akan memeriksa pencatatan dari penjualan dan akan mencatat pada formulir pendistribusian nomor seri dari tiket yang tersisa secara manual, dan melakukan perhitungan jumlah tiket yang terjual. Berikut penulis mencantumkan contoh dari formulir penyerahan tiket.

7. Pemeriksaan formulir tiket dan perhitungan PAD oleh bagaian penerimaan (kolektor) dilakukan secara manual tidak dibantu oleh peralatan elektronik. Setelah dilakukan prosedur-prosedur di atas baru akan diimput ke komputer agar lebih terealisasi lagi dan lebih terstruktur perhitungnnya.

8. Setelah dilakukan penjualan pihak UPT yang bertugas sebagai penyetor setiap harinnya akan melakukan penyetoran pendapatan pada setiap harinya dengan cara menyetorkan lansung ke Bank BRI.

Jadi dapat dikatakan bahwa Trans Padang melakukan penyerahan jasa kepada konsumen pada saat dilakukan transaksi pembelian tiket penumpang. Setiap penumpang yang mengunakan jasa transpotasi Trans Padang harus selalu membeli tiket penumpang kepada pramugara bus. Tiket yang dijual kepada pelanggan, pembayarannya dilakukan secara tunai.

\section{Pengakuan Pendapatan Trans Padang}

Berdasarkan penelitian yang dilakukakan penulis, pendapatan yang diperoleh oleh Trans Padang adalah pendapatan yang berasal dari penjualan tiket yaitu hasil penjualan secara TAT maupun secara elektronik. Pengakuan pendapatan menurut prinsip berlaku umum yang digunakan, dalam mengakui pendapatan Trans Padang mengunakan metode cash basic, yaitu pendapatan dicatat atau diakui pada saat pendapatan telah diterima atau kas telah didapatkan.

Pada saat penjualan telah terjadi atau jasa telah dilaksanakan maka akan terjadi suatu hubungan tibal balik dalam hal menerima pembayaran. Penjualan tiket Trans padang merupakan hasil dari penjualan langsung yang dilakukan pramugara Trans padang ini.

Pendapatan Trans Padang sebagai hasil dari penjualan tiket, dapat dikatakan diperoleh apabila jasa dan penjualan tiket telah dilaksanakan, tiket yang di jual kepada penumpang memiliki batas waktu yaitu untuk satu kali perjalanan.

Hal-hal yang mendasari Trans Padang mengunakan kriteria pengakuan pendapatan dari hasil penjualan tiket berdasarkan metode cahs basis, yaitu:

1. Saat penjualan tiket terjadi, dalam hal jasa transportasi yang telah dilakukan, maka pendapatan telah diakui berdasarkan transaksi penjualan.

2. Saat pembayaran dari penjualan tiket di terima secara tunai maka pendapatan telah diakui dan akan dilakukan perhitungan setelah kewajiban dilakukan. 
3. Perhitungan dan penyetoran dilakukan setelah selesainya kewajiban terhadap penumpang bus dilaksanakan.

Perusahaan yang bergerak di bidang jasa pada umumnya tidak bisa terlepas dari metode kas basis tetapi sesuai yang di sebutkan dalam SAP 71 tahun 2010 yang diamanatkan untuk keselarasan perusahaan swasta dan pemerintahan digunakan metode acrual basis, jadi pada perusahaan pemerintah diamanatkan agar mengunakan metode accrual basis.

\section{Analisis dan Evaluasi Hasil Penelitian}

Berdasarkan hasil penelitian penulis, pendapatan dari penjualan tiket pada tahun 2018 adalah sebesar Rp 7.009.765.000 untuk umum, Rp 924.427.500 untuk pelajar dan Rp 97.419.529 pendapatan dari brizzi, dengan total pendapatan berjumlah Rp 8.031.612.029 pendapatan belum sesuai dengan yang ditargetkan yaitu berjumlah Rp 10.452.778.000 dengan realisasi 76.84\%.

Kurangnya pendapatan ini adalah salah satu dampak dari kecurangan yang banyak terjadi pada saat penjualan tiket, kecurangan ini sudah merupakan rahasia publik. Oleh karena itu hendaknya ada pencegahan yang akan membuat berkurangya kecurangan yang terjadi.

\section{Analisis dan Evaluasi Pengakuan Pendapatan}

Berdasarkan hasil penelitian penulis di perusahaan, pengakuan pendapatan dari penjualan tiket dilakukan sesuai dengan penerimaan penjualan tiket di hari yang bersangkutan. Dimana pendapatan dari penjualan tersebut akan menjadi pendapatan perusahaan apabila benar-benar terjadi penjualan atau aktifitas pelayanan pemberian jasa dengan bukti penjualan tiket kepada penerima jasa. Jadi saat pengakuan pendapatan dilakukan pada saat setelah menerima kas dan memberikan pelayanan jasa angkutan umum kepada penumpang. Seperti yang telah dijelaskan di atas pengakuan pendapatan dari penjualan tiket Trans Padang akan diakui menjadi pendapatan apabila hasil dari penjualan telah diterima, dihitung dan disetorkan dengan bukti yang objektif. Dengan kata lain Trans Padang menerapkan kas basis sebagai dasar pengakuan pendapatan.

Adapun kriteria yang digunakan perusahaan Trans Padang di dasarkan pada hal-hal:

1. Hasil penjualan jasa yang menjadi pendapatan memiliki harga satuan rupiah dan dapat diukur oleh UPT Trans Padang.

2. Hasil penjualan tersebut akan mendapatkan aliran masuk berupa aktiva lancar bagi UPT Trans Padang guna disetorkan untuk pendapatan daerah.

Proses pembentukan pendapatan pada Trans Padang merupakan kegiatan penjualan tiket dengan kata lain pendapatan hanya terjadi dalam fase penjualan tiket.

Pengakuan pendapatan dari penjualan tiket Trans Padang yang mana jumlah pendapatannya dapat di ukur dengan andal, tingkat penyelesaian dari suatu transaksi dapat diukur dengan andal yang dibuktikan dengan adanya bukti formulir penyerahan tiket yang berguna untuk memudahkan dalam pencatatan dan juga pembuktian dalam pendistribusian tiket. Untuk perusahaan yang bergerak dibidang transportasi umum, saat pengakuan pendapatan merupakan saat yang paling jelas yang mana untuk mencapain tujuan penjualan tiket dapat terjadi apabila penjualan tiket serta pemberian hak kepada pelanggan telah selesai dilaksanakan.

Solusi agar Pendapatan penjualan tiket bus Trans Padang dapat dimaksimal kan apabila kecurang-kecurangan pada saat penjualan tiket dapat teratasi dengan baik dan 
benar. Solusi yang dapat penulis sarankan agar kecurangan ini tidak terus berlanjut yaitu dengan mengembangkan sistem pembayaran mengunakan tiket elektronik (brizzi) dibandingkan penjualan tiket mengunakan karcis yang rentang dengan kecurang. UPT trans padang juga bisa mengupayakan agar penjualan tiket secara manual akan lebih baik jika ditiadakan dan sistem penjualan tiket yang digunakan hanya mengunakan Tiket elektronik sehingga pendapatan bisa mencapai target yang telah di tetapkan dan perhitungan pendapatan bisa lebih terstruktur karena tidak perlu melakukan perhitungan secara manual karena data-data dari penjualan dengan sendirinya sudah terinput ke komputer.

\section{Penutup}

Simpulan

Berdasarkan penelitian yang telah dilakukan, maka penulis dapat menyimpulkan beberapa kesimpulan diantaranya:

1. Pendapatan yang diperoleh oleh Trans Padang adalah pendapatan yang berasal dari penjualan tiket angkutan bus yang terdiri dari dua macam tiket yaitu TAT dan tiket elektronik.

2. Hasil analisis pendapatan penjualan tiket pada Trans Padang ini mengunakan metode basis kas yaitu pendapatan diakui pada saat penjualan terealisasi.

3. Pendapatan dari penjuaan tiket merupakan usur paling utama kegiatan Trans Padang ini.

4. Dalam pencatatan laporan keuangan masih menggunakan metode manual sehingga banyak terjadi kesalahan-kesalahan yang signifikan.

5. Terdapatnya kesalahan pencatatan dari jumlah penjualan tiket pada tebel-tabel laporan pendapatan

6. Terdapatnya kecurangan dari penjualan tiket sehingga sangat perpengaruh terhadap pendapatan Trans Padang dalam mencapai target yang telah ditetapkan, diantaranya:

a. Tidak diberikannya tiket kepada penumpang.

b. Dibayar dibawah harga tiket tetapi tanpa tiket.

c. Terjadinya pembayaran dobel oleh penumpang yang mengira tiketnya belum dibayarkan temanya sehingga dibayar lagi oleh penumpang yang sama.

\section{Daftar Pustaka}

Adriansyah, (2015). Manajemen Transportasi dalam Kajian dan Teori. Jakarta: Universitas Prof. Dr. Moestopo Beragama.

Apsa, Sari, (2014). Evaluasi Pengakuan, Pengukuran dan Pelaporan Pendapatan Berdasarkan PSAK No.23 pada PT. Pelayaran Liba Marindo TanjungPinang Periode 2013. Tanjung Pinang: Universitas Maritim Raja Ali Haji.

Badan Pusat Statistik, (2018). Statistik Transportasi Darat 2017 (Land Transportation Statistics).Jakarta: Badan Pusat Statistik.

Dyckman, Thomas, dkk (2002). Akuntansi Inettrmediate. Edisi ketiga. Jilit Satu. Jakarta. Erlangga.

Fadhilo, Fandi, (2017). Analisis Sustainbility pada Moda Transportasi Perkotaan di Yokyakarta (Studi Kasus Jogja). Yogyakarta: Universitas Islam Negeri Sunan Kalijaga. Skripsi diterbitkan. 
Faizal, Irawan, \& Nursusanto, (2010). Perbandingan Pemberlakuan Sistem E-tiket dengan Sistem Manual Tiket Ditinjau dari Aspek Waktu atau Biaya dan Resiko. Jurnal Ilmiah Aviasi Langit Biru. Vol. 3. No. 6. Hal 1-7.

Gayatri, Gadis Ayu P, (2014). Perhitungan Harga Pokok Tiket Bus Fa LITHA dan CO. Makasar: Universita Hasanuddin. Skripsi diterbitkan.

Habibillah, Lisa, (2010). Analisis Pengakuan dan Pencatatan Pendapatan pada PT Sinepal Tour dan Travel. Batam: Politeknik Batam. Tugas Akhir diterbitkan.

Ikatan Akuntansi Indonesia, (2014). Pernyataan Standar Akuntansi Keuangan (Pendapatan) PSAK No. 23. Jakarta; Dewan Standar Akuntansi Keuangan.

Indrawati, dkk (2007). Mata Kuliah Psikodiagnostik II (Observasi). Bandung: Universitas Pendidikan Indonesia.

Ma'arif, Samsul, (2013). Analisis Faktor-Faktor Yang Mempengaruhi Pendapatan Pasar Bandarjo Ungaran Kabupaten Semarang. Semarang: Universitas Negeri Semarang. Skripsi deterbitkan.

Mulia, Budi, (2007). Pengakuan Dan Pengukuran Pendapatan Menurut PSAK NO. 23 Pada PT. Raya Utama Tavel Medan. Medan: Universitas Sumatera Utara. Skripsi diterbitkan.

Nurianti, (2013). Analisis Pengakuan Pendapatan dan Beban Pada CV.Gajah Benu Bosa Sintong (Rohil). Riau Pekanbaru: Universitas Islam Negeri Sultan Syahrif kasim Riau Pekanbaru. Skripsi diterbitkan.

Prabowo, Aan \& Heriyanto, (2013). Analisis Pemanfaatan Buku Elektronik (E-Book) Oleh Pemusatan di Perpustakaan SMA Negeri 1 Semarang. Jurnal Ilmu Perpustskaan. Vol. 2. No. 2. Hal. 1-9.

Pratikno, Herry Judhi, (2006). Analisis Intensitas Penggunaan Angkutan Penumpang Umum (Kasus Angkutan Penumpang Umum Bus Antar Kota dalam Provinsi Non Ekonomi Jurusan Semarang-Solo). Semarang: Universitas Diponegoro. Tesis diterbitkan.

Rahmat, Abdul Rohman Amat \& Octaviano, Alvino, (2016). Aplikasi Pemesanan Tiket Bus Berbasis Web (Studi Kasus pada PO. Harapan Jaya). Jurnal Informatika Universitas Pamulang. Vol. 1. No. 1. Hal. 1-11.

Republik Indonesia. (2009). Undang-Undang No. 9 Tahun 2009 Tentang Pengembangan lembaga Negara RI No 27. Presiden Republik Indonesia Jakarta.

Sa'diyah, Santi Siti \& Sutarti. (2014). Analisis Pengakuan Pendapatan dan Beban serta Pengaruhnya terhadap Laporan Rugi Laba (Studi Kasus pada PD Jasa Transportasi). Bogor: Sekolah Tinggi Ilmu Ekonomi Kesatuan.

Septiono, Amri \& Suhandak, dkk. (2015). Metode Pengakuan dan Beban terhadap Kewajaran Laporan Keuangan (Studi Kasus PT. Petrosida Gresik). Jurnal Administrasi Bisnis (JAB). Vol. 24. No. 1. Hal. 1-10.

Soegijono, (1993). Wawancara sebagai Salah Satu Metode Pengumpulan Data. Media Litbangkes. Vol. 3. No. 01. Hal. 17-21.

Sugiyono, (2011). Metode Penelitian Kualitatif. Jakarta: Salembang Empat.

Warren, Carl S, \& Reeve, James M, et al. (2017). Pengantar Akuntansi 1 (Adaptasi Indonesia Edisi 4). Jakarta: Salembang Empat.

Widjono, (2007). Bahasa Indonesia (Mata Kuliah Pengembangan Kepribadian di Perguruan Tinggi). Jakarta: Grasindo. 
Wulandari, Putri, (2013). Pengaruh Perubahan Pendapatan Penjualan Tiket Pesawat dan Kapal Pelni terhadap Perubahan pada PT. Pesona Bintan Tours dan Travel. Tanjung Pinang: Universitas Maritim Raja Haji. 